\title{
EFFECT OF INTERCROPPING OKRA AND MAIZE ON THE INFESTATION RATE WITH SOME PESTS AND THEIR ASSOCIATED PREDATORS AND ON THE RESULTANT YIELD
}

\author{
MANSOUR, ERIAN S., AMAL A. ABD-ALLAH, HOSNEA A. AFIFI, \\ NADIA H. HABASHI and MONA M. GHALLAB
}

Plant Protection Research Institute, ARC, Dokki, Giza

(Manuscript received 21 November 2016 )

\begin{abstract}
$\mathrm{F}$ ield trials were conducted in two different Governorates, Qualyoubeya (Quaha) and Sharqueya (Majazer) to study the effectiveness of different types of cropping system of okra (Hibiscus esculentus L.) against the major insect pests in order to provide comparative measures of these pests and their associated predators. The study consisted of three cropping system and control replicated each three times.Data obtained recorded that the piercing sucking pests, Tetranych usurticae Koch, Aphis gossypii Glover, Bemisia tabaci (Gennadius) were found. In addition, the bollworms, Heliothis armigera (Hübner) and Earias insulana Boisduval and their associated predators, Chrysoperla carnea (Stephens) and Coccinella undecimpunctata Linnaeus were present on okra plants. The results revealed that okra, Hibiscus esculentus L. intercropped with maize, Zea maysL. in alternating rows (1:1), treatment A,proved to be the most efficient cropping system, wherethe lowest infestation of different pestscompared to the control (the monoculture system) and the other cropping systemin the two governorates. Moreover, treatment (A)recorded the best pod yield of $78.9 \& 75.9 \mathrm{~kg} / \mathrm{karat}$ in Majazer and Quaha, respectively
\end{abstract}

Key words: Aphid, bollworms, cropping system, Earias insulana, Heliothis armigera, intercropping, okra, monoculture, piercing sucking insect, spider mites, whitefly.

\section{INTRODUCTION}

Okra, Abelmoschus (Hibiscus) esculentus, family Malvaceae (mallows), is mainly grown for its young immature pods, known as "lady's finger", or "bamia" which are consumed as a vegetable and can be conserved by drying. It is one of the popular nutritious vegetables of North-East African origin, contains many important minerals such as iron, calcium, manganese, potassium, vitamin B \& C and folic acid. The bamia pods are among the very low calorie vegetables, besides containing no saturated fats or cholesterol. Nonetheless, they are rich sources of dietary fiber;it is one of the vegetables with highest levels of anti-oxidants; often recommended by nutritionists in 
cholesterol controlling and weight reduction programs (Okra nutrition facts), also, best fibers from the stem of okra plants has industrial uses (Igor et al. 2010).

Okra plant is attacked by several pests causing economic losses in the crop yield. Theyare infested by spider mite, T.urticae whitefly, B. tabaci (Gennadius), jassid, E. lubica and aphid, A. gossypii. These pests infest leaves, stems, branches and pods during the winter.The sucking insect pests transmit viral diseases of okra such as leaf curl and stunting virus. In addition they secrete honeydew

which falls on the upper surface of the leaves resulted in growinga black sooty mould develops fungus. Also, okra plants attacked by the bollworms of $H$. armigera, which take it up as food.Pods and flowers are primary targets of spiny bollworm, $E$. insulana, while the American bollworm caterpillar, $H$. armigera prefers the reproductive parts of the plant, including buds, flowers and fruits (Mudathir, 2000).There is always a pressing need for surveying, identifying and studying the activity of important pests infesting this crop in the field.

In Egypt,many authors studied the effect of intercropping system throughout certain crops combinations such as Metwally (1978) and Shafshak et al. (1984) and Ghallab et al. (2005), it is a popular system of cultivation for maximizing yields of cropsEl-Khouly et al.(1994). Several authors have reported that infestation rates and pest populations are reduced in poly- culture system than in monoculture of different field crops Altieri et al. (1978); Sharaf-El-Din et al. (1993); Rizk et al. (2002), Abro et al. (2004).

The objective of this work was planned to clarify the effect of okra grown in monoculture and in mix cropping systemsokra and maizeon theinfestation rate of pests' and their associatedpredatorsand theyield crop.

\section{MATERIALS AND METHODS}

The field experimentwere conducted at different sites, atthe Agricultural Research station "Quaha"in Qualyoubeya Governorate and at "Majazer" in Sharqueya Governorate, in order to provide comparative measures of different pests and their associated natural enemies.

An area of about $700 \mathrm{~m}^{2}$ (4 Karats) in both sites (Quahaand Majazer) was divided into four equal plots comprised four different types of cultivations as follows:

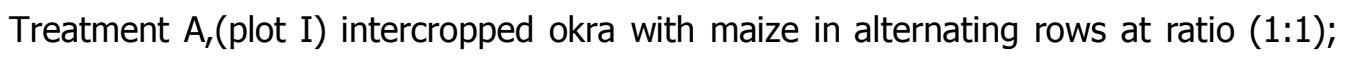
Treatment $B$, (plot II) intercropped okra with maize in alternating rows at ratio (2:1); Treatment C, (plot III)cultivated okra surrounded by two rows of maize; Treatment D (plot VI), cultivated okra as monoculture (Check control). 
Each plot with 9 ridges (3 replicates) of 5 meters length and $60 \mathrm{~cm}$ apart; all normal cultural practices of land preparation, thinning, irrigation, mechanical weed control were followed out and kept free from any insecticidal application.

Okra seeds were planted about 2-3 cm deep in a single row on top of the ridgeson 10 April 2014 while those of maize were sown one month later.

\section{A - Counting of the piercing sucking pests and the abundance of the associated predators}

Sampling started on May $16^{\text {th }}$ and continued weekly until the $18^{\text {th }}$ of July. Samples of 10 leaves of okra plants from each replicatemaking a sum of 30 leaves for each treatment were picked randomly from three levels of the plant. Each sample were kept in tight close paper bag and transferred to the laboratory to estimate the different piercing sucking pests attacked the leaf surface and their associated predators by the aid of the Sterio-binocular microscope.

\section{B - Estimating the rate of damage caused by bollworms:}

The infestation of $E$. insulana and $H$. armigera in monoculture and mix crops okra and maize was assessed by estimating the damage caused by borers. The percentage fruit damage by larvae was evaluated by counting the total and attacked number of fruits in a sample of 10 pods of okra selected at random per treatment.The observations were taken at weekly intervals. The data were recordedfrom a monthafter sowing of seeds in the fieldtill harvest of the crop.

\section{C - Estimating the crop yield of different treatments}

Themean okra yield (in $\mathrm{Kg}$ ) were estimated for each treatment per Karat or feddan; fruits of 10 plants / treatment were picked and weighed.

\section{Statistical Analysis}

Data subjected to Portable statistical analysis SAS 9.3.1. to determine the significance between means of the tested intercropping systems at the two governorates.

\section{RESULTS AND DISCUSSION}

\section{Populationof different pests in relation to cultivation system}

Three piercing sucking pests, T.urticae, A.gossypii and B. tabaci; two bollworms, $H$. armigera and $E$. insulana Boisduval and two predators, C. undecimpunctata and $C$. carnea were concerned in this study.

Data in Tables (1\&2) show weekly counts of mean numbers of the motile stages\&eggs of spider mites, adult \& nymphs of aphidand nymphs\&eggs of whitefly 
on ten okra leaves in each treatment in both sites of the study area (Quaha), Qualyoubeya and (Majazer) Sharqueya Governorates).

\section{1- Spider mite, T.urticae}

Among the different treatments in the two sites, all cropping systems registered low infestation by spider mites. There are high significant differences between the mean numbers in Treatment (A) and (B)and those in the control plot. Treatment (A) recordedthe lowest infestation of means 4 \& 3.6 individuals in Quaha and Majazer, respectively, while were lower than those of the check plot $17.3 \& 9.1$ individuals, respectivelywith high significant differences.No significant differences between the mean numbers in treatment (C) of $11.6 \& 6.9$ individualscompared to control17.3 \& 9.1 individuals in Quaha and Majazer, respectively.

The total numbers of eggs deposited by T.urticae on leaves of okra plants in the two sites were showed in Tables (1\& 2). The highest mean number of eggs recorded in treatment (C) in the two sites, followed by treatment (B) recorded 5.5 \& 5.3 eggs, and 6.9 \& 4.4 eggs, in Quaha and Majazer, respectively; while the lowest mean numbers of eggs was recorded in treatment (A) 4.4 \& 3.9 eggs in Quaha and Majazer, respectively, compared to those of control $11.1 \& 16.3$ eggs . The statistical analysis proved the significant differences between mean numbers of eggs in the check plot and alltreatments except the treatment $(C)$ in Majazer.

The present results go in line with the finding of Mohanasundaram et al. (2012), they indicated thatall the intercropping treatments significantly reduced the leafhopper, whitefly, red spider mite and fruit damage.

\section{2 -Whitefly, B. tabaci}

According to the different cultivation systems, the treatment $(A)$ showed the lowest attraction of whitefly, $B$.tabaci population amounted 5.1individuals followed by treatments $(B)$ then $(C)$ with average 6.6\&6.8 individuals, respectively in Qualyoubeya Governorate, while the control showed the mean number 7.7 individuals withno significant differences between meanswere observed; the same trend was observed in Sharqueya Governorate.

In Majazer region, an obvious increase in population of whitefly in control plot of mean reaching 17.2 individuals which is more than twice the individuals collected from Quaha region which was 7.7 individualsbut in both regions, there were no significant differences between mean numbers in all intercropping systems and their corresponding control. 
Table 1. The mean numbers of piercing sucking pests on okra leaves in Quaha

\begin{tabular}{|c|c|c|c|c|c|c|c|c|c|c|}
\hline \multirow{2}{*}{ Date } & \multicolumn{4}{|c|}{ Tetranychusurticae } & \multirow{2}{*}{ Total } & \multicolumn{4}{|c|}{ Eggs of Tetranychusurticae } & \multirow{2}{*}{ Total } \\
\hline & Cont. & A & B & C & & Cont. & $A$ & B & C & \\
\hline 16-May & 5 & 4 & 4 & 32 & 45 & 27 & 13 & 4 & 5 & 49 \\
\hline 23-May & 4 & 5 & 4 & 11 & 24 & 17 & 11 & 4 & 5 & 37 \\
\hline 30-May & 26 & 4 & 9 & 10 & 49 & 15 & 7 & 7 & 7 & 36 \\
\hline 6-Jun. & 28 & 1 & 15 & 9 & 53 & 6 & 4 & 4 & 8 & 22 \\
\hline 13-Jun. & 29 & 3 & 16 & 11 & 59 & 8 & 7 & 2 & 7 & 24 \\
\hline 20-Jun & 28 & 2 & 21 & 12 & 63 & 9 & 1 & 27 & 7 & 44 \\
\hline 27-Jun & 18 & 2 & 8 & 3 & 31 & 7 & 1 & 0 & 4 & 12 \\
\hline 4-Jul. & 23 & 5 & 11 & 6 & 45 & 1 & 0 & 5 & 3 & 9 \\
\hline 11- Jul. & 6 & 12 & 0 & 19 & 37 & 21 & 0 & 0 & 9 & 30 \\
\hline 18- Jul. & 6 & 2 & 3 & 3 & 14 & 0 & 0 & 0 & 0 & $\mathbf{0}$ \\
\hline Total & 173 & 40 & 91 & 116 & 420 & 111 & 44 & 53 & 55 & 263 \\
\hline Mean & 17.3 & 4 & 9.1 & 11.6 & & 11.1 & 4.4 & 5.3 & 5.5 & \\
\hline LSD at $5 \%$ & \multicolumn{4}{|c|}{7.2} & & \multicolumn{4}{|c|}{5.5} & \\
\hline
\end{tabular}

\begin{tabular}{|c|c|c|c|c|c|c|c|c|c|c|}
\hline \multirow{2}{*}{ Date } & \multicolumn{4}{|c|}{ Whiteflies } & \multirow{2}{*}{ Total } & \multicolumn{4}{|c|}{ Eggs of Whiteflies } & \multirow{2}{*}{ Tota } \\
\hline & Cont. & A & B & C & & Cont. & $A$ & B & C & \\
\hline 16-May & 4 & 1 & 7 & 5 & 17 & 12 & 7 & 3 & 8 & 30 \\
\hline 23-May & 4 & 3 & 7 & 5 & 19 & 11 & 6 & 2 & 8 & 27 \\
\hline 30-May & 8 & 6 & 6 & 8 & 28 & 5 & 3 & 5 & 5 & 18 \\
\hline 6-Jun. & 24 & 8 & 4 & 0 & 36 & 0 & 1 & 0 & 0 & 1 \\
\hline 13-Jun. & 15 & 7 & 7 & 12 & 41 & 1 & 3 & 5 & 5 & 14 \\
\hline 20-Jun & 5 & 5 & 7 & 6 & 23 & 1 & 2 & 1 & 0 & 4 \\
\hline 27-Jun & 8 & 4 & 14 & 21 & 47 & 5 & 0 & 0 & 3 & 8 \\
\hline 4-Jul. & 4 & 2 & 3 & 2 & 11 & 17 & 2 & 5 & 7 & 31 \\
\hline 11- Jul. & 2 & 5 & 1 & 4 & 12 & 12 & 0 & 3 & 1 & 16 \\
\hline 18- Jul. & 3 & 10 & 10 & 5 & 28 & 1 & 0 & 0 & 1 & 2 \\
\hline Total & 77 & 51 & 66 & 68 & 262 & 65 & 24 & 24 & 38 & 151 \\
\hline Mean & 7.7 & 5.1 & 6.6 & 6.8 & & 6.5 & 2.4 & 2.4 & 3.8 & \\
\hline LSD at $5 \%$ & & & & & & & & & & \\
\hline
\end{tabular}

\begin{tabular}{|c|c|c|c|c|c|}
\hline \multirow{2}{*}{ Date } & \multicolumn{4}{|c|}{ aphid } & \multirow{2}{*}{ Tota } \\
\hline & Cont. & A & B & C & \\
\hline 16-May & 0 & 0 & 4 & 6 & 10 \\
\hline 23-May & 0 & 4 & 5 & 5 & 14 \\
\hline 30-May & 20 & 4 & 6 & 21 & 51 \\
\hline 6-Jun. & 41 & 0 & 0 & 38 & 79 \\
\hline 13-Jun. & 55 & 6 & 25 & 20 & 106 \\
\hline 20-Jun & 98 & 6 & 13 & 9 & 126 \\
\hline 27-Jun & 89 & 3 & 5 & 33 & 130 \\
\hline 4-Jul. & 80 & 7 & 12 & 46 & 145 \\
\hline 11- Jul. & 5 & 2 & 3 & 10 & 20 \\
\hline 18- Jul. & 15 & 3 & 13 & 12 & 43 \\
\hline Total & 403 & 35 & 86 & 200 & 724 \\
\hline Mean & 40.3 & 3.5 & 8.6 & 20 & \\
\hline LSD at $5 \%$ & \multicolumn{4}{|c|}{17.2} & \\
\hline
\end{tabular}

Cont. = Okra in monoculture ; $\mathrm{A}=1: 1$ (okra : maize) $; \mathrm{B}=2: 1$ (okra: maize) ; $\mathrm{C}=\mathrm{Okra}$ surrounded by maize 
Table 2. The mean numbers of piercing suking pests on okra leaves in Majazer

\begin{tabular}{|c|c|c|c|c|c|c|c|c|c|c|}
\hline \multirow{2}{*}{ Date } & \multicolumn{4}{|c|}{ Tetranychusurticae } & \multirow{2}{*}{ Total } & \multicolumn{4}{|c|}{ Eggs of Tetranychusurticae } & \multirow{2}{*}{ Total } \\
\hline & Cont. & A & B & C & & Cont. & $A$ & $\mathrm{~B}$ & C & \\
\hline 16-May & 8 & 3 & 2 & 5 & 18 & 4 & 3 & 2 & 0 & 9 \\
\hline 23-May & 6 & 4 & 5 & 4 & 19 & 6 & 5 & 4 & 6 & 21 \\
\hline 30-May & 0 & 0 & 0 & 3 & 3 & 0 & 0 & 6 & 0 & 6 \\
\hline 6-Jun. & 15 & 5 & 8 & 8 & 36 & 57 & 6 & 6 & 25 & 94 \\
\hline 13-Jun. & 18 & 11 & 10 & 8 & 47 & 76 & 10 & 4 & 25 & 115 \\
\hline 20-Jun & 14 & 4 & 8 & 2 & 28 & 10 & 0 & 0 & 8 & 18 \\
\hline 27-Jun & 5 & 0 & 2 & 9 & 16 & 0 & 0 & 4 & 0 & 4 \\
\hline 4-Jul. & 9 & 5 & 7 & 10 & 31 & 8 & 7 & 6 & 5 & 26 \\
\hline 11- Jul. & 11 & 4 & 11 & 20 & 46 & 2 & 8 & 12 & 0 & 22 \\
\hline 18- Jul. & 5 & 0 & 0 & 0 & 5 & 0 & 0 & 0 & 0 & $\mathbf{0}$ \\
\hline Total & 91 & 36 & 53 & 69 & 249 & 163 & 39 & 44 & 69 & 315 \\
\hline Mean & 9.1 & 3.6 & 5.3 & 6.9 & & 16.3 & 3.9 & 4.4 & 6.9 & \\
\hline LSD at $5 \%$ & \multicolumn{4}{|c|}{2.9} & & \multicolumn{4}{|c|}{10.57} & \\
\hline
\end{tabular}

\begin{tabular}{|c|c|c|c|c|c|c|c|c|c|c|}
\hline \multirow{2}{*}{ Date } & \multicolumn{4}{|c|}{ Whiteflies } & \multirow{2}{*}{ Total } & \multicolumn{4}{|c|}{ Eggs of Whiteflies } & \multirow{2}{*}{ Total } \\
\hline & Cont. & $A$ & B & C & & Cont. & A & B & C & \\
\hline 16-May & 105 & 6 & 14 & 10 & 135 & 79 & 4 & 4 & 4 & 91 \\
\hline 23-May & 2 & 7 & 14 & 10 & 33 & 22 & 2 & 5 & 4 & 33 \\
\hline 30-May & 7 & 8 & 12 & 32 & 59 & 29 & 4 & 6 & 5 & 44 \\
\hline 6-Jun. & 7 & 8 & 14 & 20 & 49 & 8 & 2 & 2 & 4 & 16 \\
\hline 13-Jun. & 9 & 7 & 16 & 19 & 51 & 2 & 3 & 1 & 2 & 8 \\
\hline 20-Jun & 39 & 6 & 18 & 13 & 76 & 0 & 1 & 1 & 3 & 5 \\
\hline 27-Jun & 0 & 3 & 4 & 5 & 12 & 3 & 0 & 2 & 2 & 7 \\
\hline 4-Jul. & 0 & 1 & 0 & 0 & 1 & 0 & 0 & 1 & 0 & 1 \\
\hline 11- Jul. & 0 & 5 & 2 & 1 & 8 & 0 & 0 & 0 & 0 & 0 \\
\hline 18- Jul. & 3 & 4 & 1 & 2 & 10 & 0 & 0 & 0 & 0 & 0 \\
\hline Total & 172 & 55 & 95 & 112 & 434 & 143 & 16 & 22 & 24 & 205 \\
\hline Mean & 17.2 & 5.5 & 9.5 & 11.2 & & 14.3 & 1.6 & 2.2 & 2.4 & \\
\hline LSD at $5 \%$ & \multicolumn{4}{|c|}{15.2} & & \multicolumn{4}{|c|}{13.11} & \\
\hline
\end{tabular}

\begin{tabular}{|c|c|c|c|c|c|}
\hline \multirow{2}{*}{ Date } & \multicolumn{4}{|c|}{ aphid } & \multirow{2}{*}{ Total } \\
\hline & Cont. & $A$ & $B$ & C & \\
\hline 16-May & 1 & 11 & 0 & 1 & 13 \\
\hline 23-May & 4 & 0 & 4 & 4 & 12 \\
\hline 30-May & 77 & 1 & 50 & 36 & 164 \\
\hline 6-Jun. & 4 & 7 & 4 & 4 & 19 \\
\hline 13-Jun. & 3 & 0 & 4 & 1 & 8 \\
\hline 20-Jun & 4 & 1 & 8 & 2 & 15 \\
\hline 27-Jun & 16 & 3 & 2 & 32 & 53 \\
\hline 4-Jul. & 0 & 15 & 13 & 5 & 33 \\
\hline 11- Jul. & 5 & 42 & 3 & 4 & 54 \\
\hline 18- Jul. & 2 & 3 & 0 & 0 & 5 \\
\hline Total & 116 & 83 & 88 & 89 & 376 \\
\hline Mean & 11.6 & 8.3 & 8.8 & 8.9 & \\
\hline LSD at $5 \%$ & \multicolumn{4}{|c|}{12.4} & \\
\hline
\end{tabular}

Cont. $=$ Okra in monoculture $; \mathrm{A}=1: 1$ (okra : maize) $; \mathrm{B}=2: 1$ (okra: maize) $; \mathrm{C}=$ Okra surrounded by maize 
Tantawy et al. (1989) attributed lower populations of whitefly and thrips in cowpea intercropped with maize was due to the greater height of maize plants which may shelter the crop from pest infestation.

In case of $B$. tabaci eggs, the three cultivation systems recorded lower numbers of eggsby the mean numbers2.4, 2.4, 3.8 eggs, for treatments (A), (B)and (C), respectively, with a significant difference comparing to the control 6.5 eggs. Moreover, the number of the whitefly eggs in Majazer region in the control plot was appeared in high numbers (twice) more than Quaha region. In both locations, there were insignificant differences between all treatments.

\section{3- Aphid, A. gossypii}

Among the different cultivation systems, treatment $(A)$ recorded the lowest attraction of aphids with mean numbers3.5 individualsfollowed by (B), then (C) of mean numbers 8.6 and 20individuals, respectively, but, with no significant differences between means and highly significant difference comparing to the control which counted 40.3 individuals in Quaha, Qualyoubeya Governorate. In Majazer, Sharqueya Governorate, the population of aphiddecreased obviouslyin control plot of mean reaching 11.6 individuals which is very few than those individuals collected from Quaha region which was 40.3 individuals and withno significant differences between means of other cropping systems.

Previous results are in agreement with the finding of El-khouly et al. (1994) who reported that intercropping of maize with cowpea in different patterns is suitable for decreasing the infestation rare of both crops with the cowpea aphid and the corn leaf aphid. Moreover, Ghallab et al. (2005) proved that intercropping tomato with pumpkin caused relatively high reduction in numbers of Collembola, aphids, leafhoppers and Thrips sp. This reduction of pests could be explained according to Parfait \& Jerry (1987), who stated that intercropping may reduce pest dispersion, due to the change of microclimate caused by the presence of the second crop thus affecting the biology of the pest at different stages of its development. Subsequently the density of insect population and its infestation degree evidently decrease.

\section{Population of bollworms in relation to cultivation systems}

Data in Tables 3 ( $a \& b$ ) show weekly counts of mean numbers of two bollworms, $H$. armigera and $E$. insulana of ten okra pods in each cultivation systems in both sites of the study, (Quaha and Majazer). The infested fruit with borer were recorded at each picking and their weight was noted. The fruits were weighed separately and their infestation due to fruit borer was recorded for each treatment. 
Table 3 a. The mean numbers of cotton bollworms in ten okra pods in Quaha

\begin{tabular}{|c|c|c|c|c|c|c|c|c|c|c|}
\hline \multirow{2}{*}{ Date } & \multicolumn{4}{|c|}{ Eariasinsulana } & \multirow{2}{*}{ Total } & \multicolumn{4}{|c|}{ Heliothisarmigera } & \multirow{2}{*}{ Total } \\
\hline & Cont. & $\mathrm{A}$ & B & C & & Cont. & A & $\mathrm{B}$ & C & \\
\hline 16-May & \multirow[b]{4}{*}{2} & \multirow[b]{4}{*}{0} & \multirow[b]{4}{*}{2} & \multirow[b]{4}{*}{2} & \multirow[b]{4}{*}{6} & \multirow[b]{4}{*}{2} & \multirow[b]{4}{*}{1} & \multirow[b]{4}{*}{1} & \multirow[b]{4}{*}{1} & \multirow[b]{4}{*}{5} \\
\hline 23-May & & & & & & & & & & \\
\hline 30-May & & & & & & & & & & \\
\hline 6-Jun. & & & & & & & & & & \\
\hline 13-Jun. & 5 & 1 & 4 & 4 & 14 & 3 & 1 & 2 & 1 & 7 \\
\hline 20-Jun & 9 & 5 & 4 & 5 & 23 & 6 & 3 & 3 & 4 & 16 \\
\hline 27-Jun & 12 & 5 & 4 & 7 & 28 & 12 & 5 & 8 & 7 & \multirow{2}{*}{$\begin{array}{l}32 \\
39\end{array}$} \\
\hline 4-Jul. & 19 & 9 & 9 & 11 & 48 & 15 & 8 & 9 & 7 & \\
\hline 11- Jul. & 23 & 11 & 12 & 15 & 61 & 21 & 9 & 11 & 11 & 52 \\
\hline 18- Jul. & 26 & 15 & 15 & 22 & 78 & 24 & 14 & 12 & 15 & 65 \\
\hline Total & 96 & 46 & 50 & 66 & 258 & 83 & 41 & 46 & 46 & 216 \\
\hline Mean & 9.6 & 4.6 & 5.0 & 6.6 & & 8.3 & 4.1 & 4.6 & 4.6 & \\
\hline LSD at $5 \%$ & & & & & & & & & & \\
\hline
\end{tabular}

Table $3 \mathrm{~b}$. The mean number of cotton bollworms in ten okra pods in Majazer

\begin{tabular}{|c|c|c|c|c|c|c|c|c|c|c|}
\hline \multirow{2}{*}{ Date } & \multicolumn{4}{|c|}{ Eariasinsulana } & \multirow{2}{*}{ Total } & \multicolumn{4}{|c|}{ Heliothis } & \multirow{2}{*}{ Tota } \\
\hline & Cont. & $A$ & B & C & & Cont. & A & B & $\mathrm{C}$ & \\
\hline 16-May & \multirow[b]{5}{*}{2} & \multirow[b]{5}{*}{0} & \multirow[b]{5}{*}{0} & \multirow[b]{5}{*}{1} & \multirow[b]{5}{*}{3} & \multirow[b]{5}{*}{4} & \multirow[b]{5}{*}{0} & \multirow[b]{5}{*}{0} & \multirow[b]{5}{*}{2} & \multirow[b]{5}{*}{6} \\
\hline 23-May & & & & & & & & & & \\
\hline 30-May & & & & & & & & & & \\
\hline 6-Jun. & & & & & & & & & & \\
\hline 13-Jun. & & & & & & & & & & \\
\hline 20-Jun & 3 & 1 & 1 & 1 & 6 & 3 & 1 & 3 & 0 & 7 \\
\hline 27-Jun & 4 & 2 & 4 & 2 & 12 & 5 & 2 & 2 & 1 & 10 \\
\hline 4-Jul. & 6 & 3 & 6 & 7 & 22 & 9 & 3 & 4 & 3 & 19 \\
\hline 11- Jul. & 12 & 6 & 9 & 12 & 39 & 12 & 4 & 5 & 9 & 30 \\
\hline 18- Jul. & 23 & 10 & 15 & 20 & 68 & 25 & 10 & 8 & 12 & 55 \\
\hline Total & 50 & 22 & 35 & 43 & 150 & 58 & 20 & 22 & 27 & 127 \\
\hline Mean & 5.0 & 2.2 & 3.5 & 4.3 & & 5.8 & 2.0 & 2.2 & 2.7 & \\
\hline LSD at $5 \%$ & & & & & & & & & & \\
\hline
\end{tabular}

\section{1-Spotted bollworm, E. insulana}

Tables 3 ( $a \& b$ ) show the effects of different cropping systems of okra on population of $E$. insulana indicated that the okra cropped with maize in alternating rows at ratio $1: 1$, treatments $(A)$, was the best system, where a low infestation of 
Earias sp. was observed amounted $4.6 \& 2.2$ individuals in the two regions, Quaha and Majazer, respectively, followed by treatments (B) then (C) The data revealed significant differences between treatments (all cropping systems) and control in Quaha, whereas in Majazer, the significant differences was only between treatment $(A)$ and control. The results indicated that no significant differences between all treatments.

This result was coinciding with that of Abro et al. (2004) who indicated that pest infestation in mix crop was recorded two weeks later than monoculture; so, Earias sp. infestation in okra grown as mono crop remained higher than in okra grown as mix crop, recorded $24.9 \& 12 \%$, respectively.

\section{2-American bollworm, $\boldsymbol{H}$. armigera}

The results in Tables 3 (a \& b) showed significant differences between different treatments and control in both regions, while no significant differences between all treatments.

Regarding the effect of treatments in the two sites, treatment $(A)$ recorded the lowest infestation by $H$. armigera of means $4.1 \& 2.0$ individuals in Quaha and Majazer, respectively which, were lower than those of the check plot $8.3 \& 5.8$ individuals, respectively with high significant differences; while no significant differences compared to treatment (B) \& (C).

This finding was coinciding with Ofuya (1991)who recorded that damage by $H$. armigera was significantly higher in sole cowpea than in cowpea intercropped with tomato. Also, Sundararajan and Chitra, (2012),registered the sucking pests' whitefly, B. tabaci, leaf hopper, Empoasca sp. and the pod borer, Heliothis sp. caused low damage in sorghum intercropped blackgram plants.

\section{Population of predators in different cultivation systems}

Data in tables 4 ( $a \&$ b) show weekly counts of mean numbers of two predators $C$. undecimpunctata and C.carneafrom different cultivation systems throughout the period from May $16^{\text {th }}$ until July $18^{\text {th }}$ onokra plants.

According to LSD, the mean numbers of the predaceous insects, the ladybird and the green lacewing captured from okra contoured by maize (treatment $\mathrm{C}$ ) were $1.0 \& 1.3$ individuals for Coccinella sp. and Chrysoperlla sp., respectively, represent the highest occurrence and exceeded those collected from (treatments A \& B) recorded $0.69 \& 0.79$ individuals of Coccinella sp. and $1.04 \& 1.26$ individuals of Chrysoperla sp without significant differences. Moreover, Majazer region harbored higher mean numbers of these previous predators in Treatment $C, 1.27 \& 1.38$ individuals, respectively, more than the two other treatments A \& B without significant differences. 
Table $4 \mathrm{a}$. The average numbersof twopredatorson ten okra leaves in Quaha

\begin{tabular}{|c|c|c|c|c|c|c|c|c|c|c|}
\hline \multirow{2}{*}{ Date } & \multicolumn{4}{|c|}{ Coccinellaundecimpunctata } & \multirow{2}{*}{ Total } & \multicolumn{4}{|c|}{ Chrysoperllacarnea } & \multirow{2}{*}{ Total } \\
\hline & Cont. & $A$ & B & C & & Cont. & A & B & $\mathrm{C}$ & \\
\hline 16-May & 0.6 & 0.2 & 0.4 & 0.6 & 1.8 & 1.8 & 0.4 & 0.6 & 0.8 & 3.6 \\
\hline 23-May & 1.2 & 0.6 & 0.8 & 1.0 & 3.6 & 2.2 & 1 & 1.2 & 1.4 & 5.8 \\
\hline 30-May & 1.3 & 1.2 & 0.5 & 0.4 & 3.4 & 2.4 & 1.6 & 0.9 & 0.8 & 5.7 \\
\hline 6-Jun. & 2.0 & 0.3 & 0.7 & 1.2 & 4.2 & 2.1 & 0.6 & 0.9 & 1.2 & 4.8 \\
\hline 13-Jun. & 2.6 & 0.4 & 0.8 & 1.4 & 5.2 & 2.1 & 0.8 & 1.0 & 1.2 & 5.1 \\
\hline 20-Jun & 3.2 & 0.6 & 1.0 & 1.6 & 6.4 & 2.5 & 0.8 & 1.0 & 1.4 & 5.7 \\
\hline 27-Jun & 4.1 & 1.2 & 0.8 & 0.6 & 6.7 & 3.3 & 1.2 & 1.4 & 1.6 & 7.5 \\
\hline 4-Jul. & 4.6 & 0.4 & 0.9 & 1.2 & 7.1 & 3.5 & 1.4 & 1.8 & 1.6 & 8.3 \\
\hline 11- Jul. & 5.1 & 0.6 & 0.8 & 1.0 & 7.5 & 5.0 & 1.6 & 2.0 & 1.4 & 10 \\
\hline 18- Jul. & 5.3 & 1.4 & 1.2 & 1.0 & 8.9 & 4.4 & 1 & 1.8 & 1.6 & 8.8 \\
\hline Total & 30.0 & 6.9 & 7.9 & 10.0 & 54.8 & 29.3 & 10.4 & 12.6 & 13 & 65.3 \\
\hline Mean & 3.00 & 0.69 & 0.79 & 1.00 & & 2.93 & 1.04 & 1.26 & 1.3 & \\
\hline LSD at $5 \%$ & \multicolumn{4}{|c|}{0.77} & & \multicolumn{4}{|c|}{0.42} & \\
\hline
\end{tabular}

Table $4 \mathrm{~b}$. The average numbersof twopredatorson ten okra leaves in Majazer

\begin{tabular}{|c|c|c|c|c|c|c|c|c|c|c|}
\hline \multirow{2}{*}{ Date } & \multicolumn{4}{|c|}{ Coccinellaundecimpunctata } & \multirow{2}{*}{ Total } & \multicolumn{4}{|c|}{ Chrysoperllacarnea } & \multirow{2}{*}{ Total } \\
\hline & Cont. & A & B & $\mathrm{C}$ & & Cont. & $\mathrm{A}$ & $\mathrm{B}$ & $\mathrm{C}$ & \\
\hline 16-May & 0.3 & 0.1 & 0.1 & 0.2 & 0.7 & 0.7 & 0.5 & 0.3 & 0.4 & 1.9 \\
\hline 23-May & 0.4 & 0.2 & 0.1 & 0.3 & 1 & 1.1 & 0.7 & 0.6 & 0.8 & 3.2 \\
\hline 30-May & 0.7 & 0.4 & 0.02 & 0.7 & 1.82 & 2.3 & 1.4 & 1.2 & 1 & 5.9 \\
\hline 6-Jun. & 1.4 & 0.7 & 0.8 & 1.2 & 4.1 & 1.8 & 0.8 & 1 & 0.7 & 4.3 \\
\hline 13-Jun. & 1.9 & 1 & 1.2 & 1.3 & 5.4 & 2.2 & 1 & 1.2 & 0.9 & 5.3 \\
\hline 20-Jun & 2.5 & 1.5 & 1 & 1 & 6 & 2.7 & 1.2 & 1.5 & 1 & 6.4 \\
\hline 27-Jun & 2.8 & 1.8 & 2 & 2.2 & 8.8 & 3.2 & 2 & 1.6 & 1.4 & 8.2 \\
\hline 4-Jul. & 3.6 & 2.2 & 2.6 & 2.2 & 10.6 & 3.7 & 1.7 & 1.9 & 1.8 & 9.1 \\
\hline 11- Jul. & 4 & 1.5 & 2.2 & 1.8 & 9.5 & 4.4 & 2.4 & 2.2 & 2.8 & 11.8 \\
\hline 18- Jul. & 5 & 1.2 & 1.6 & 1.8 & 9.6 & 4.6 & 2 & 1.8 & 3 & 11.4 \\
\hline Total & 22.6 & 10.6 & 11.62 & 12.7 & $\mathbf{5 7 . 5 2}$ & 26.7 & 13.7 & 13.3 & 13.8 & 67.5 \\
\hline Mean & 2.26 & 1.06 & 1.16 & 1.27 & & 2.67 & 1.37 & 1.33 & 1.38 & \\
\hline
\end{tabular}


Regarding the total number of predators, it appear that the region Majazer harbored the highest number of Chrysoperla and Coccinella ( $67.5 \& 57.5$ individuals), respectively, compared to those collected from Quaha region recorded $65.3 \& 54.8$ individuals, respectively.

This finding in agree with Kares et al. (1993) and Shalaby et al. (1983), who proved that cotton surrounded by maize on the periphery of the plots refuge thehighest numbers of predators followed by cotton and maize in alternating rows at the ratio (2:1), then cotton and maize at the ratio (1:1). Also, these data in accordance with the concept of Agnew \& Smith (1989) who determined the abundance of predators could be a result of high numbers of herbivores in dense foliage of maize which offer shade, protection and humidity and favorable to predators.

\section{Total fruit yield}

Results concerning total okra pods yield of the four mix crops, in the two governorates, are presented in (Table, 5). The highest total okra pods yield was obtained in treatments (A) amounted $75.9 \& 78.9 \mathrm{Kg}$. / Karat, followed bytreatments (C) then (B) $70.6 a n d 69.6 \mathrm{Kg}$ / Karat in Quaha and Majazer, respectively.

Table 5. Yield of okra podsfrom each cultivation systemin kg. / Karatin Qualyoubeya and Sharqueya Governorates

\begin{tabular}{|l|c|c|}
\hline \multirow{2}{*}{ System of cultivation } & \multicolumn{2}{|c|}{ Total yield in k.g. / Karat } \\
\cline { 2 - 3 } & Quaha (Qualyoubeya) & Majazer (Sharqueya) \\
\hline Rows of okra to maize, $1: 1$ & $\mathbf{7 5 . 9}$ & $\mathbf{7 8 . 9}$ \\
\hline Rows of okra to maize, $2: 1$ & 69.6 & $\mathbf{6 9 . 6}$ \\
\hline Okra surrounded by maize & $\mathbf{7 0 . 6}$ & $\mathbf{7 0 . 6}$ \\
\hline & & $\mathbf{6 8 . 3 7}$ \\
\hline
\end{tabular}

Mean of harvested okra pods yield in the previous cropping systems exceeded that of the control (untreated) which recorded the lowest total okra pods yield of 68.73 \& $68.37 \mathrm{Kg}$. / Karat in the two regions. 


\section{CONCLUSION}

From the results obtained, it can be concluded that it is more advantageous to intercrop okra and maize. Intercropping generally, not only minimizes risks of pest infestations but also,it is associated with a higher predaceous insects and a greater total intercrop yield.

\section{REFERENCES}

1. Okra nutrition facts; www.nutrition-and-you.com

2. Abro, G. H.; A. J. Memon; T. S. Syed and A. A. Shaikh. 2004. Infestation of Earias spp. on cotton and okra grown as monoand mix crops. Pakistan J. Biol. Sci. 7(6): $937-942$.

3. Agnew, C. W. and J. W. Smith. 1989. Ecology of spiders (Araneae) in a peanut

4. agroecosystem .Environ.Entomol. $18: 30-42$.

5. Altieri, M. A.; C. A. Francis; A. Schoonhooven and I. D. Doll. 1978. A review of insect prevalence in maize,Zea maize L.and bean, Phaseolus vulgaris polyculture systems. (Field crop Res. 1 (1) : $33-40$.

6. El-Khouly, A. S.; M. A. Ali; I. L. Ibrahim and S. A. Naga. 1994. Effect of intercroppingmaize and cowpea on theirsusceptibility to infestation with aphids.Bull. Entom. Soc. Egypt (ARE), Vol.72: 229 - 235.

7. Ghallab, M. M.; N. H. Habashy and M.A. Rizk. 2005. "A Comparative study between four different patterns of farming system and their effect on the activitydensity of some arthropods. J. Egypt.Ger. Soc. Zool.: (48E) Entomol.: 81 - 99.

8. Igor, Maria De Rosa; José Maria Kenny; D. Puglia; C. Santulli and F. Sarasini. 2010. Morphological, thermal and mechanical characterization of okra (Abelmoschus esculentus) fibres as potential reinforcement in polymer composites. Composites Sciences and Technology, Vol. 70 (1), January $2010,: 116-122$.

9. Kares, E. A.; A. A. Hafez; E. F. El-Khayatand F. F. Shalaby. 1993. Sunflower and maize in plantations to increase the natural role of entomophagous insects. Annals Agric. Sci. Moshtohor Vol. 31(2) : 1199 -1211.

10. Metwally, A. A. 1978. Solid and intercropping soybeans and corn. Ph. D. Thesis, Fac. of Agric. Cairo Univ. 
11. Mohanasundaram, A; R.K. Sharma and K. Sharma. 2012. Eco-friendly management of major insect pests of okra with intercropping and newer molecules. Indian Journal of Plant Protection Vol. 40. (1) :32 - 37.

12. Mudathir, M. 2000. Studies on the control of insect pests in vegetables (okra, tomato, and onion) in Sudan with special reference to neem preparations. Faculty of Agrarwissenschaften, Ökotrophlogie und Umweltmanagement University of Giessen, Ph. D. 122 pp.

13. Ofuya, T. I. 1991. Observations on Insect Infestation and Damage in Cowpea (Vigna Unguiculata) Intercropped With Tomato (Lycopersicon Esculentum) in a Rain Forest Area of Nigeria. Exp. Agric. 27 (4) : $407-412$.

14. Parfait, S. and M. Jerry. 1987. Plant diversity and impact of phytophagous insects, a bibliographic review of methods applied in the case of mixed cultures. Oecologia - generalis 5 (3) : $363-379$.

15. Rizk, M. A. ; A. K. Iskander; L. S. Sourialand N. H. Habashy 2002. Effect of intercropping of guar (Cyompois tetragonolaba) Leguminosae, with tomato on level infestation of sucking pests infesting tomato . The $2^{\text {nd International }}$ Conference: The role of IPM to obtain a safe agriculture productand an environment free of pollution, December, 21 -24, 2002 Giza - Egypt .

16. Shafshak, S. E. ; S. A. Shokr and H. Shafik. 1984. Intercropping of maize and soyabean as affected by various nitrogen levels. II- Yield and yield components Proc. $2^{\text {nd }}$ Gen. ARC. , Giza , 9 -11 April .

17. Shalaby, F. F.; E. A. Kares and A. A. Ibrahim. 1983. Effect of intercropping maize in cotton fields on the attractiveness of predaceous insects.Annals Agric. Sci. Moshtohor Vol. 20 : $109-123$.

18. Sharaf-El-Din, A. A.; I. I. Ismaeil; M.A. Ali, and M.Y. Hashem. 1993. Effect of intercropping systems and planting methods on the population of onion pests Bull. Ent. Soc. Egypt . $71: 139-152$.

19. Soundararian, R. P. and N. Chitra. 2012. Impact of Intercrops on Insect Pests of Blackgram, Vigna mungo L.Journal of Entomol. , 9: 208-219.

20. Tantawy, A. M.; F. Haydarand A. H. Shaheen. 1989. The effect of intercroppingwith soybean and cowpea in maize on the major pests attacking each crop. $1^{\text {st }}$ Intern. Conf. Ent., Cairo, Egypt, vol. 1: 219- 228. 


\section{تأثير تحميل البامية بالذرة على معدل الإصابة ببعض الآفات

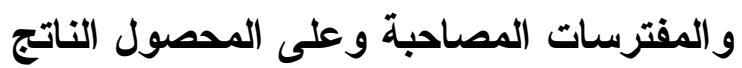

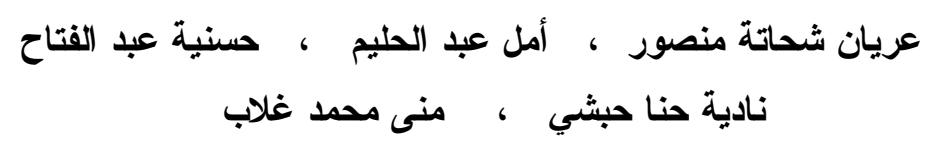

معهد بحوث وقاية النباتات - مركز البحوث الزراعية - الدقي - الجيزة

تصاب البامية بالعديد من الآفات مثل العنكبوت الأحمر، و الذبابة البيضاء، والتربس، و المن، وديدان اللوز وتسبب هذه الآفات خسائر تؤُثر على جودة المحصول. ونظراً للضرر الذي تسبيه هذه الآفات على محصول البامية نم دراسة تأثير نظم مختلفة من الغطاء النباتي و الزر اعي لونى (التحميل،

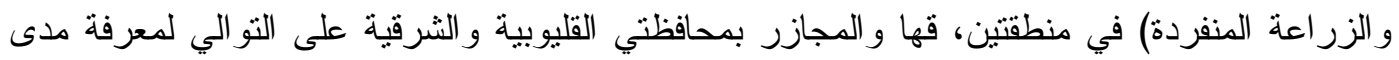

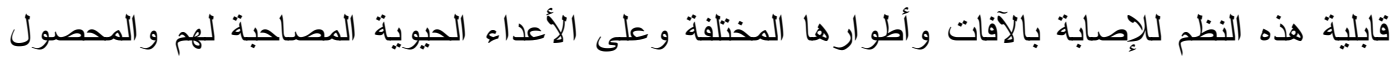

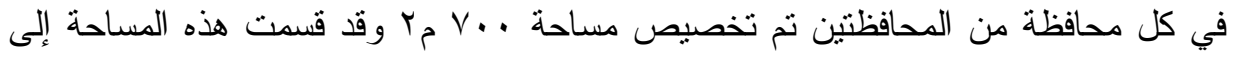

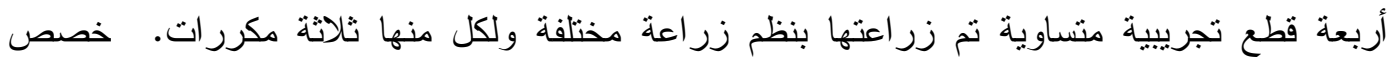

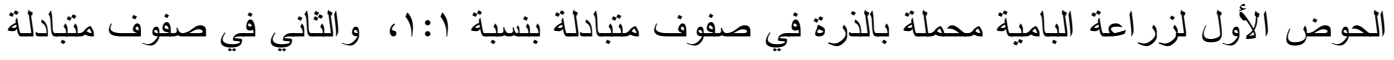
بنسبة r: ا، و الثالث البامية محاطة بخطين من الذرة، و الر ابع زر اعة البامية منفردة (المقارنة).

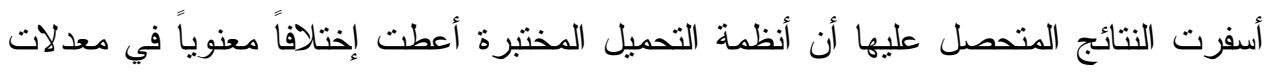
الإصابة بالآفات المختلفة مقارنة بالزراعة المنفردة (المقارنة) في كلا المنطقتين، فقد أصيبت نباتات البامية المنزرعة بدون تحميل بأعلى تعداد من الآفات المختلفة بينما أعطى تحميل البامية بالذرة بنسبة بادية

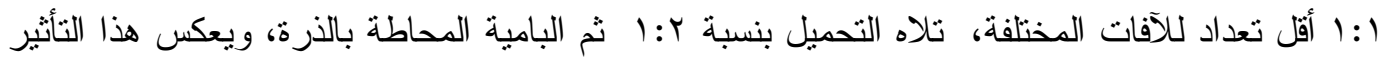
الغير مباثر لهذا النظام الزر اعي فيما يخص المكافحة الحيوية.

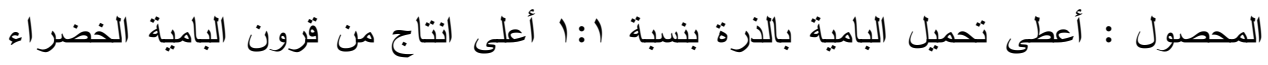

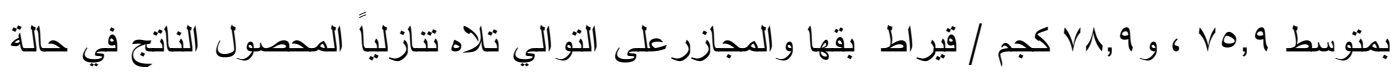

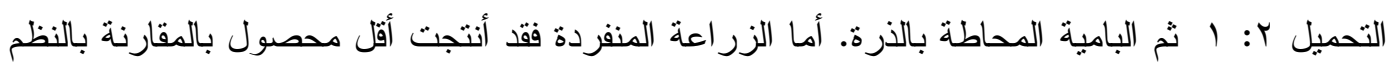

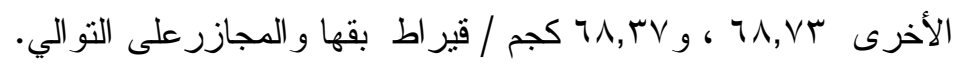

